\title{
PERANAN WANITA KARIER TERHADAP PEMBINAAN KECERDASAN SPIRITUAL DAN PEMBENTUKANKARAKTER ANAK DI KECAMATAN TAPA KABUPATEN BONE BOLANGO
}

\author{
Yeni Marlina Hamdjati dan Djailani Haluty \\ Pascasarjana IAIN Sultan Amai Gorontalo \\ email : yenimarlina695@gmail.com
}

\begin{abstract}
Wanita karier dalam pembahasan tesis ini adalah seorang ibu yang berkiprah pada dunia kerja dan mampu mengasuh dan mendidik anak-anaknya, sehingga daripadanya dapat memberi dampak posisitif yang cukup besar kepada anak dalam hal pembinaan spiritual dan pembentukan karakter anak. Permasalahan yang diangkat dalam tesis ini adalah: Pertama, bagaimana tingkat partisipasi wanita karier dalam pembinaan spiritual dan pembentukan karakter anak di Kecamatan Tapa Kabupaten Bone Bolango? Kedua, bagaimana upaya yang dilakukan wanita karier dalam pembinaan spiritual dan pembentukan karakter anak di Kecamatan Tapa Kabupaten Bone Bolango? Tujuan dari penelitian ini adalah untuk mendeskripsikan tentang tingkat partisipasi dan upaya yang dilakukan wanita karier dalam pembinaan spiritual dan pembentukan karakter anak di Kecamatan Tapa Kabupaten Bone Bolango.

Metode penelitian yang digunakan dalam penelitian ini adalah metode kualitatif deskriptif, dengan pendekatan yuridis normatif, sosilogis-kultural, dan pendekatan psikologis serta teknik pengumpulan data melalui observasi, analisis, wawancara, dan daftar informan.

Hasil penelitian menunjukkan bahwa; 1) Tingkat Partisipasi Wanita karier dalam Pembinaan Spiritual dan Pembentukan Karakter Anak di Kecamatan Tapa Kabupaten Bone Bolango ditunjukkan melalui pengasuhan anak sepenuhnya dilakukan oleh orang tua, pembiasaan atau pemberian contoh teladan kepada anak-anak dalam lingkup penanaman akhlakul qarimah, orang tua selalu memperhatikan cara belajar anak, orang tua membuat program kegiatan yang harus dilakukan oleh anak-anaknya dalam setiap hari, orang tua meskipun aktivitas keseharian lebih banyak berada di luar rumah, tetapi selalu berusaha untuk memenuhi tugas dan tanggung jawabnya dalam mendidik anak-anaknya agar memiliki pengetahuan aqidah dan akhlak secara dini serta mampu mengaplikasikan nilai-nilai aqidah dan akhlak terpuji dalam kehidupan sehari-hari; 2) Upaya yang dilakukan wanita karier dalam pembinaan spiritual dan pembentukan karakter anak di Kecamatan Tapa Kabupaten Bone Bolango di antaranya; a) melakukan pendidikan aqidah dan akhlak secara intesif kepada anak melalui mempraktekkan amalan ibadah di dalam kehidupan sehari-hari, seperti shalat lima waktu, puasa, membaca al-Qurean, dan amalan ibadah lainnya. Sedangkan pendidikan akhlak dilakukan dengan cara penanaman etika dan moral dalam keluarga, memperkenalkan kepada anak-anak cara hidup menghargai sesama manusia dan makhluk lainnya di lingkungan sekitarnya, serta mengajari anak agar selelu bersyukur dan bersabar untuk mengakui kebesaran Ilahi atas apa yang terjadi kepada makhluk ciptaan-Nya; b) memberikan contoh ketaladan yang baik kepada anak pada semua aspek; c) memasukkan anak ke lembaga-lembaga pendidikan agama, atau mengikutsertakan anak pada setiap kegiatan keagamaan, serta membiasakan anak membaca buku-buku tentang Aqidah dan Akhlak; d) melakukan pengawasan terhadap semua aktivitas anak terutama; cara belajar anak, sikap ramah anak terhadap orang lain, cara bergaul anak dengan yang lebih muda, sederajat atau yang lebih tua, yang kesemuanya disertai dengan penetapan puneshman dan reward atas perbuatan yang mereka lakukan.
\end{abstract}




\section{A. PENDAHULUAN}

Salah satu isu yang tak pernah kering untuk dibicarakan dan selalu menarik untuk dibahas di tengah mencuatnya seribu satu macam isu adalah kesetaraan gender laki-laki versus perempuan serta berbagai upaya yang telah dilakukan untuk memperjuangkannya. Kesetaraan gender yang selalu diperjuangkan itu tidak lain adalah agar kaum wanita bisa tampil di berbagai lapangan pekerjaan atau turut sertanya wanita di kancah perpolitikan yang selama ini didominasi kaum pria.

Munculnya gagasan tentang peran wanita bekerja di luar rumah atau lebih dipopulerkan dengan istilah wanita karier diawali dengan asumsi yang mengatakan bahwa perempuan adalah manusia yang paling berjasa bagi lahirnya generasi baru yang kuat dan tangguh, yang merasa diri termarjinalkan bahkan nyaris tidak diberikan peluang untuk berkiprah sama seperti laki-laki.

Meskipun demikian, Islam memiliki pandangan khusus terhadap wanita. Islam pertama muncul di jazirah Arab dimana wanita pada masa itu seperti barang dagangan dan perbedaan status yang sangat jauh dengan lelaki. Akan tetapi Islam datang untuk menghapus itu dan datang menyamakan kedudukan wanita dengan laki-laki. Dari sisi insaniyyah nya wanita dan laki-laki adalah sama, tidak ada penghalang dikarenakan perbedaannya dalam meraih kedudukan yang tinggi disisi Allah. Sebagaimana firman Allah dalam QS. Ali Imran (3): 195

Terjemahnya:

...Sesungguhnya Aku tidak menyia-nyiakan amal orang-orang yang beramal di antara kamu, baik laki-laki atau perempuan, sebagian kamu adalah turunan dari sebagian yang lain...

Di dalam Islam kita telah mengenal Sayyidah Fatimah Azzahra (putri Rasulullah) yang membela dan mendampingi perjuangan Ayahnya, Sayyidah Maryam yang dengan kelembutannya menjaga sang kekasih Allah, Isa Almasih, juga Sayyidah Asiah (istri Firaun) yang dengan kesabarannya bisa terjaga dari pengaruh buruk Firaun.

Kompetisi hidup dan tekanan ekonomi global dewasa ini pun sering kali menuntut wanita untuk bekerja guna memenuhi kebutuhan keluarga. Berbagai jenis pekerjaan dilakukan, 
Jurnal Ilmiah Al-Jauhari (JIAJ)

Studi Islam dan Interdisipliner

Volume 3 No 2 September 2018

ISSN 2541-3430 E-ISSN 2541-3449

seperti menjadi buruh, pembantu rumah tangga, pedagang kecil, dan pekerjaan-pekerjaan lain.

Perempuan yang bekerja karen tidak ada pilihan lain selain harus bekerja kita sebut ,„pekerja perempuan ${ }^{e e}$.

Menyinggung tentang eksistensi wanita karier tak lepas dari isu yang banyak digulirkan, yaitu emansipasi. Namun berdasarkan asal muasal gerakan ini digulirkan (tumbuh sejak awal abad XX), propaganda gerakan ini justru munculnya dari laki-laki dan hanya terdapat sedikit saja wanita.

Awalnya gerakan emansipasi hanyalah seruan kepada pemerintah untuk memperhatikan kesempatan pendidikan akademis bagi wanita. Seruan ini cukup mendapat simpati karena aktivitasnya mengarah kepada peningkatan kecerdasan, keleluasaan generasi baru yang lebih cakap dan berkualitas. Namun seiring perkembangan zaman mereka tidak saja menyerukan pentingnya mendapatkan pendidikan, tapi juga menyampaikan aspirasi tentang pentingnya persamaan derajat, kebebasan, peningkatan karier di segala bidang.

Di Kecamatan Tapa Kabupaten Bone Bolango, wanita karier keberadaannya dianggap sangat membantu memperkuat ekonomi keluarga baik bersifat primer maupun bersifat sekunder seperti; dapat membantu suaminya untuk membeli dan memenuhi kebutuhan makan dan minum keluarga, dapat membantu menyediakan tempat tinggal keluarga, dapat membeli pakaian anakanaknya, dan dapat membiayai anaknya dalam studi, serta kegiatan-kegiatan sosial lainnya.

Hal menarik lagi sesuai hasil observasi awal penulis bahwa, keberadaan wanita karier di Kecamatan Tapa Kabupaten Bone Bolango dapat memberi motivasi bagi kaum pria untuk meningkatkan kinerja dalam suatu organisasi, sebab wanita karier tersebut diberikan peluang yang cukup besar untuk menduduki posisi sebagai camat, kepala desa, kepala dusun, juga sebagai ketua kepanitiaan pada kegiatan-kegiatan instansi dan keumatan.

Berdasarkan hal di atas mendorong penulis untuk mengkaji secara langsung kondisi riil yang ada, apakah kesibukan tugas yang digeluti oleh wanita karier di Kecamatan Tapa Kabupaten Bone Bolango masih dapat menyisihkan waktu atau berkesempatan bagi mereka untuk melakukan pembinaan kecerdasan spiritual terhadap pembentukan karakter anak-anak mereka ataukah sebaliknya. 
Mengacu pada uraian latar belakang di atas, maka penulis mengangkat satu permasalahan pokok untuk dijadikan kajian utama dalam penelitian ini, yaitu "bagaimana peran wanita karier terhadap pembinaan kecerdasan spiritual dan pembentukan karakter anak di Kecamatan Tapa Kabupaten Bone Bolango". Untuk mengerucutkan pembahasan, penulis membatasinya pada sub masalah sebagai pembatasan objek kajian sebagai berikut;

1. Bagaimana tingkat partisipasi wanita karier dalam pembinaan kecerdasan spiritual dan pembentukan karakter anak di Kecamatan Tapa Kabupaten Bone Bolango?

2. Bagaimana upaya yang dilakukan wanita karier dalam pembinaan kecerdasan spiritual dan pembentukan karakter anak di Kecamatan Tapa Kabupaten Bone Bolango?

3. Kendala apa saja yang dialami oleh wanita karier dalam pembinaan kecerdasan spiritual dan pembentukan karakter anak di Kecamatan Tapa Kabupaten Bone Bolango, serta bagaimana solusinya? 
Jurnal Ilmiah Al-Jauhari (JIAJ)

Studi Islam dan Interdisipliner

Volume 3 No 2 September 2018

ISSN 2541-3430 E-ISSN 2541-3449

\section{B. LANDASAN TEORI}

\section{Hakikat Wanita Karier}

Diskursus tentang wanita karier dewasa ini semakin hangat, terutama di negeri ini telah mendapatkan dukungan serta perhatian serius dari berbagai kalangan, khususnya yang menamakan diri mereka kaum Feminis dan pemerhati wanita. Pengungkungan Islam terhadap wanita dan mempromosikan motto emansipasi dan persamaan hak di segala bidang tanpa kecuali atau yang belakangan lebih dikenal dengan sebutan kesetaraan gender tidak ada yang mempermasalahkan lagi.

Dalam konstitusi di Indonesia, wanita memiliki kedudukan yang sama dengan laki-laki. Hal ini tersebut dalam Firma Allah dalam QS al-Jumuª ah (62) :10

Terjemahnya:

Apabila telah ditunaikan shalat, maka bertebaranlah kamu di muka bumi; dan carilah karunia Allah dan ingatlah Allah banyak-banyak supaya kamu beruntung.

Demikian pula dalam UUD tahun 1945 Bab XII pasal 27, bahwa "semua warga negara bersamaan kedudukannya di dalam hukum dan pemerintahan". hal ini mengindikasikan bahwa antara laki-laki dan perempuan mempunyai hak, kedudukan dan peran yang sama untuk berpartisipasi dalam pembangunan nasional. Namun pada kenyataannya umumnya sebagian perempuan malah sangat dibatasi dalam hal ruang geraknya

\section{Tinjauan Hukum bagi Wanita Karier}

Beragam corak sosio-kultural, tingkat pendidikan, dan berbagai aspek lainnya telah mengakibatkan berbagai pandangan tentang eksistensi wanita dalam masyarkat. Secara umum saat ini model pemahaman tentang wanita terbagi atas dua versi yaitu antara pemahaman Barat dan pemahaman Timur. Untuk lebih jelas Penulis akan menguraikan lebih jauh dalam bab ini; 


\section{Wanita Karier Versi Barat}

Dalam dunia Barat, paham wanita karier muncul sebagai suatu bentuk keinginan untuk setara dengan laki-laki dalam segala hal yang sering mereka gaungkan dengan istilah "Kesetaraan Gender". Selain itu, dari sisi historis, terjunnya kaum wanita ke lapangan untuk bekerja dan berkarier semata-mata karena unsur keterpaksaan. Ada dua hal penting yang melatarbelakanginya:

Pertama, terjadinya revolusi industri mengundang arus urbanisasi kaum petani pedesaan, tergiur untuk mengadu nasib di perkotaan, karena himpitan sistem kapitalis yang melahirkan tuan-tuan tanah yang rakus.

Kedua, kaum kapitalis dan tuan-tuan tanah yang rakus sengaja menggunakan momen terjunnya kaum wanita dan anak-anak, dengan lebih memberikan porsi kepada mereka di lapangan pekerjaan, karena mau diupah lebih murah daripada kaum lelaki, meskipun dalam jam kerja yang panjang.

\section{Wanita Karier Versi Islam}

Islam adalah agama yang sangat menghargai kerja, ketekunan dan kerja keras. Itulah sebabnya Kalau kita kembali menelaah keterlibatan wanita dalam pekerjaan terlebih pada masa awal Islam, maka tidaklah berlebihan jika dikatakan bahwa Islam membenarkan mereka aktif dalam berbagai aktivitas.

Menurut Quraish shihab, Islam tidak melarang perempuan berkarier atau menolak menjadi pemimpin selain di rumah tangga. Sebab tidak ditemukan dasar yang kuat bagi larangan seorang perempuan untuk berkarier atau menjadi pemimpin di ruang publik. Allah berfirman dalam QS. an-Nahl (16) : 97

Terjemahnya:

Barangsiapa yang mengerjakan amal saleh, baik laki-laki maupun perempuan dalam keadaan beriman, maka sesungguhnya akan Kami berikan kepadanya kehidupan yang baik dan sesungguhnya akan Kami beri balasan kepada mereka dengan pahala yang lebih baik dari apa yang telah mereka kerjakan. 
Berdasarkan ayat al-Quran di atas, Quraish Shihab menambahkan bahwa perempuan dibolehkan berkarier atau menjadi pemimpin di ruang publik. Prinsip yang mendasari kebolehan wanita berkarier adalah prinsip yang berlaku dalam segala hal adalah kebolehan, sampai ada dalil yang menunjukkan ketidakbolehan. Bahkan dalam hadis Nabi Muhammad saw disebutkan:

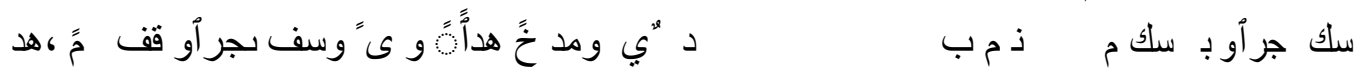

Artinya;

Tidaklah seseorang memperoleh suatu penghasilan yang lebih baik dari jerih payah tangannya sendiri. Dan tidaklah seseorang menafkahi dirinya, istrinya, anaknya dan pembantunya melainkan ia dihitung sebagai sadaqah.

Satu hal yang perlu dikatahui bahwa pekerjaan dan aktivitas yang dilakukan oleh wanita pada masa Nabi cukup beraneka ragam, sampai-sampai mereka terlibat secara langsung dalam beberapa peperangan dan bahu-membahu dengan kaum lelaki. Nama-nama seperti Ummu Salamah (istri Nabi), Shafiyah, Laila Al-Ghaffariyah, Ummu Sinam Al-Aslamiyah, dan lain-lain, tercatat sebagai tokoh-tokoh yang terlibat dalam peperangan. Ahli hadis, Imam Bukhari, membukukan bab-bab dalam kitab Shahih-nya, yang menginformasikan kegiatan-kegiatan kaum wanita, seperti Bab Keterlibatan wanita dalam Jihad, Bab Peperangan Perempuan di Lautan, Bab Keterlibatan Perempuan Merawat Korban, dan lain-lain.

Selanjutnya, dalam bidang perdagangan, nama istri Nabi yang pertama, Khadijah binti Khuwailid, tercatat sebagai seorang yang sangat sukses. Demikian juga Qilat Ummi Bani Anmar yang tercatat sebagai seorang wanita yang pernah datang kepada Nabi untuk meminta petunjukpetunjuk dalam bidang jual-beli. Istri Nabi saw., Zainab binti Jahsy, juga aktif bekerja sampai pada menyamak kulit binatang, dan hasil usahanya itu beliau sedekahkan. Raithah, istri sahabat Nabi Abdullah ibn Maseeud, sangat aktif bekerja, karena suami dan anaknya ketika itu tidak mampu mencukupi kebutuhan hidup keluarga ini. Al-Syifa ${ }^{e e}$, seorang wanita yang pandai menulis, ditugaskan oleh Khalifah Umar r.a. sebagai petugas yang menangani pasar kota Madinah. 
Jurnal Ilmiah Al-Jauhari (JIAJ)

Studi Islam dan Interdisipliner

Volume 3 No 2 September 2018

ISSN 2541-3430 E-ISSN 2541-3449

Wanita mempunyai kedudukan sama dengan laki-laki kecuali dalam beberapa hal yang harus disesuaikan dengan nalurinya. Karenanya, dalam hal ini wanita memperoleh prioritas untuk dimuliakan dan diperlakukan lemah lembut sebagimana layaknya. Keberadaan wanita dalam Islam yang begitu sempurna ini tidak dijumpai dalam agama lain. Islam sebenarnya tidak melarang seorang wanita bekerja atau melalui kegitatan di luar rumah, asal tidak melampaui batas kodrat kewanitaannya.

Tugas seorang ibu rumah tangga, kata al-Ghazali seorang ulama Mesir kontemporer adalah tugas yang amat mulia. Seorang istri dapat saja keluar untuk pekerjaan tertentu, tetapi betapapun pentingnya pekerjaan itu ia tidak boleh meninggalkan serta mengalahkan tugas utamanya sebagai ibu rumah tangga yang tidak mungkin dapat digantikan oleh orang lain. Tugas-tugas utama itu antara lain:

Pertama, wanita sebagai istri. Kedudukan istri dalam keluarga adalah sangat penting, karena kebahagian atau kesengsaraan yang terjadi dalam keluarga banyak ditentukan oleh sikap istri. Kedua Wanita pun di posisikan sebagai ibu rumah tangga. Peranan wanita sebagai ibu rumah tangga menempati posisi yang sangat urgent, karena dari rahim ibulah bayi-bayi akan lahir. Ketiga wanita sebagai istri, sebagai anggota keluarga maupun sebagai ibu rumah tangga harus lebih di utamakan daripada tugas dan aktivitas di luar kepentingan keluarga.

Dalam tinjauan syariat, Islam sebenarnya tidak melarang seorang wanita bekerja atau melakukan kegiatan di luar rumah. Hanya saja ada beberapa hal yang harus di perhatikan, yaitu:

1) Pakaian yang digunakan harus sesuai dengan aturan Islam

2) Tidak melalaikan tugasnya sebagai ibu rumh tangga

3) Tidak menurunkan martabatnya sebagai wanita dan sesuai dengan fitrah dan kejiwaan wanita pada umumnya

4) Tidak melanggar ajaran Islam mengenai hubungan antar pria dan wanita dengan persetujuan suami. 
Jurnal Ilmiah Al-Jauhari (JIAJ)

Studi Islam dan Interdisipliner

Volume 3 No 2 September 2018

ISSN 2541-3430 E-ISSN 2541-3449

\section{Faktor-faktor yang Mempengaruhi Pembinaan Spiritual dan Pembentukan Karakter Anak}

Para ahli sependapat bahwa spiritual dan karakter itu berkembang dan mengalami perubahan-perubahan. Tetapi di dalam pekembangan itu makin terbentuklah pola-pola yang tetap dan khas, sehingga merupakan ciri-ciri yang unik bagi setiap individu. Karakter anak yang perlu dibentuk agar tumbuh menjadi manusia dewasa yang berkepribadian luhur tidak terlepas dari 18 (delapan belas) karakter yaitu; relegius, jujur, toleransi, disiplin, kerja keras, kreatif, mandiri, demokrasi, rasa ingin tahu, semangat, cinta tanah air, menghargai prestasi, bersahabat, gemar membaca, cinta damai, peduli lingkungan, peduli sosial, dan tanggung jawab.

Menurut Sjarkawi, faktor-faktor yang mempengaruhi spiritual dan karakter seseorang dapat dikelompokkan dalam dua faktor, yaitu faktor internal dan eksternal:

\section{Faktor Internal}

Faktor internal adalah faktor yang berasal dari dalam diri orang itu sendiri. Faktor internal ini biasanya merupakan faktor genetis atau bawaan.

\section{Faktor Eksternal}

Faktor eksternal adalah faktor yang berasal dari luar orang tersebut. Faktor eksternal ini biasanya merupakan pengaruh yang berasal dari lingkungan seseorang mulai dari lingkungan terkecilnya, yakni keluarga, teman, tetangga, sampai dengan pengaruh dari berbagai media audiovisual seperti TV dan VCD, atau media cetak seperti koran, majalah dan lain sebagainya.

Dalam upaya membina spiritual dan karakter anak pada umumnya yang mengandung unsur-unsur kognisi, afeksi, dan psikomotor, Sjarkawi mengatkan ada tiga unsur yang perlu diperhatikan yaitu:

1. Unsur kognisi di antaranya sebagai berikut: pertama, orangtua harus meyakini bahwa anak sebagai makhluk sosial yang sedang berkembang sarat dengan masalah etika dan moral; kedua, orangtua harus memahami bahwa dalam proses pembentukan spiritual dan karakter, anak dapat belajar dari berbagai sumber. ketiga orangtua harus memahami bahwa pendidikan yang dilakukan oleh orangtua mampu memberikan manfaat pada anak karena didasarkan pada etika dan moral; keempat, orangtua memiliki pertimbangan dan pemikiran yang cermat, jernih, teliti, manusiawi, dan penuh tanggung jawab, dan 
Jurnal Ilmiah Al-Jauhari (JIAJ)

Studi Islam dan Interdisipliner

Volume 3 No 2 September 2018

ISSN 2541-3430 E-ISSN 2541-3449

dilandasi etika moral akan mampu mendidik anak-anaknya menuju pada spiritual dan karakter yang utuh.

Unsur-unsur kognisi tersebut di atas dapat diturunkan kedalam pola prilaku afektif di antaranya sebagai berikut: pertama, memberikan penghargaan dan penghormatan yang setinggi-tingginya terhadap kehidupan manusia yang penuh muatan etika dan moral; kedua, berupaya sesuai dengan tanggung jawab yang dimiliki, ikut mengimplementasikan dan mengembangkan secara optimal etika dan moral pada anak secara profesional; ketiga, berusaha seoptimal mungkin memberikan keteladanan kepada anak yang berlandaskan pada etika dan moral; keempat bersikap positif terhadap pentingnya etika dan moral dan diwujudkan dalam keseluruhan aktivitas di lingkungan keluarga.

Penyikapan secara afeksi tersebut dapat secara nyata diwujudkan dalam bentuk psikomotor, yang di antaranya sebagai berikut: pertama orangtua harus memperlihatkan sifatsifat kesedehanaan, rendah hati, sabar, menepati janji, dapat dipercaya, serta harus penuh rasa tanggung jawab; kedua orangtua bersifat terbuka terhadap saran dan kritik yang diberikan kepadanya dan harus mengusahakan tanggung jawab dan keihklasan yang tinggi; ketiga, orangtua harus menghormati harkat dan hak-hak pribadi, serta menjadikan pribadinya sebagai contoh teladan bagi anak-anaknya; keempat, orangtua dalam membina spiritual dan karakter anak tidak membeda-bedakan antara anak yang satu dengan yang lainnya; kelima, orangtua harus berspiritual dan karakter empatik, simpatik, dan tutur bahasa yang sopan, baik dan benar serta santun; keenam, orangtua harus dapat menciptakan iklim keluarganya yang kondusif (aman, nyaman, bahagia, dan sejahtera).

Berdasarkan uraian di atas, penulis dapat menyimpulkan Upaya pembentukan spiritual dan karakter anak akan dapat diwujudkan dengan baik apabila orangtua memiliki spiritual dan karakter yang menunjang dalam melaksanakan tugas keprofesionalannya.

Anak adalah anggota keluarga, di mana orangtua adalah pemimpin keluarga, sebagai penanggung jawab atas keselamatan warganya di dunia dan khususnya di akhirat. Maka orangtua wajib mendidik anak-anaknya. Allah berfirman dalam QS. at-Tahrim (66):

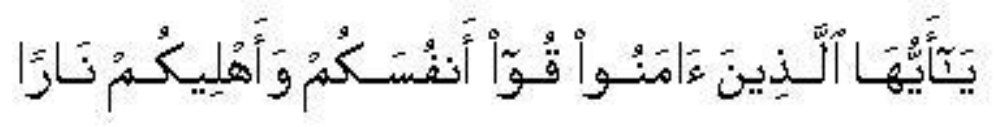


Jurnal Ilmiah Al-Jauhari (JIAJ)

Studi Islam dan Interdisipliner

Volume 3 No 2 September 2018

ISSN 2541-3430 E-ISSN 2541-3449

Terjemahnya:

"Hai orang-orang yang beriman, lindungilah dirimu dan keluarga dari siksaan api neraka". 


\section{METODOLOGI PENELITIAN}

Metode yang digunakan dalam penulisan tesis ini adalah metode kualitatif, yakni prosedur penelitian yang bergantung pada pengamatan kualitatif terhadap objek yang diteliti dan menghasilkan data-data deskriptif, berupa kata-kata tertulis atau informasi lisan dari orang-orang dan prilaku yang diamati.

Dalam menjalankan aktivitas penelitian, penulis menempuh prosedur penelitian yang relevan dengan pokok masalah yang diangkat dalam tesis ini. Prosedur-prosedur tersebut meliputi; jenis penelitian, pendekatan penelitian, lokasi peneltian, prosedur pengumpulan data, analisis data, pengecekan keabsahan temuan, dan tahap-tahap penelitian.

\section{Jenis Penelitian}

Jenis penelitian yang digunakan dalam tesis ini adalah penelitian deskriptif/non statistik atau deskriptif-kualitatif. Pengertian secara teoritis tentang penelitian deskriptif adalah penelitian yang terbatas pada usaha mengungkapkan suatu masalah dan keadaaan sebagaimana adanya, sehingga hanya merupakan penyingkapan fakta dengan menganalisa data.

Dalam penelitian deskriptif ini penulis berusaha mencatat, menganalisis, dan menginterpretasikan kondisi yang ada artinya mengumpulkan informasi tentang keadaan yang ada dengan variabel yang menjadi indikasi dalam penelitian ini.

Dengan demikian, pemaparan secara kualitatif dalam penelitian ini dimaksudkan untuk menggambarkan lebih jelas realitas tentang peranan wanita karier terhadap pembinaan kecerdasan spiritual dan pembentukan karakter anak di Kecamatan Tapa Kabupaten Bone Bolango.

\section{Lokasi Penelitian}

Penelitian ini berlokasi di Kecamatan Tapa Kabupaten Bone Bolango Provinsi Gorontalo. Lokasi ini penulis pilih sebagai obyek penelitian, oleh karena penulis merasa tertarik dengan eksistensi wanita karier di kecamatan tersebut, di mana di Kacamatan Tapa ini memiliki Aparatur Sipil Negara Wanita karier yang berjumlah 90 orang, sedangkan pria hanya berjumlah 70 orang. 
Jurnal Ilmiah Al-Jauhari (JIAJ)

Studi Islam dan Interdisipliner

Volume 3 No 2 September 2018

ISSN 2541-3430 E-ISSN 2541-3449

\section{Sumber Data}

Yang dimaksud dengan sumber data dalam hal ini adalah, "subyek dari mana data dapat diperoleh". Sumber data dalam penelitian ini meliputi data primer dan sekunder. Sumber data primer merupakan sumber yang langsung memberikan data kepada peneliti. Data primer tesis ini bersumber dari analisis terhadap jumlah yang telah ditentukan dalam wawancara (interview) dengan pihak-pihak yang dianggap memahami masalah yang diteliti.

\section{Teknik Pengumpulan Data}

Untuk memperoleh data yang sesuai dengan permasalahan penelitian, maka teknik yang digunakan dalam pengumpulan data ini meliputi: (1) observasi, (2) wawancara, dan (3) dokumentasi.

a) Observasi

Observasi adalah pengamatan yang dilakukan secara sengaja, sistematis mengenai fenomena sosial dengan gejala-gejala psikis yang kemudian dilakukan pencatatan. Sedangkan Sutrisno Hadi mendefinisikan observasi sebagai penamaan dan pencatatan dengan sistemais terhadap fenomen-fenomena yang diselidiki.

b) Wawancara

Wawancara adalah penelitian yang berlangsung secara lisan antara dua orang atau lebih dalam bentuk tatap muka, mendengarkan secara langsung mengenai informasi-informasi atau keterangan dari yang diteliti.

c) Dokumentasi

Dokumentasi peneliti digunakan untuk mengumpulkan data dari sumber-sumber non insani (bukan manusia). Dalam hal ini dokumen digunakan sebagai sumber data karena dokumen dapat dimanfaatkan dalam membuktikan, menafsirkan dan meramalkan dalam suatu peristiwa. Adapun dokumen yang dimaksud dalam penelitian ini adalah dokumen-dokumen yang diambil dari Kantor Kecamatan Tapa Kabupaten Bone Bolango, serta Badan Pusat Statistik dan Kantor Pencatatan Sipil sebagai pelengkap, seperti jumlah penduduk di Kecamatan Tapa, Keadaan Penduduk berdasarkan tingkat pendidikan dan mata pencahariannya.

\section{Analisis Data}

Analisis data yang digunakan dalam penelitian ini dimulai dari pengumpulan data, reduksi data, penyajian data, dan penarikan kesimpulan/ verifikasi. 
Jurnal Ilmiah Al-Jauhari (JIAJ)

Studi Islam dan Interdisipliner

Volume 3 No 2 September 2018

ISSN 2541-3430 E-ISSN 2541-3449

a. Pengumpulan data, dalam tahap ini peneliti melakukan studi awal melalui dokumentasi dan observasi.

b. Reduksi data, dalam tahap ini peneliti memilah dan memilih data mana yang dianggap relevan dan penting yang berkaitan dengan masalah peranan wanita karier terhadap pembinaan kecerdasan spiritual dan pembentukan karakter anak di Kecamatan Tapa Kabupaten Bone Bolango. Sedangkan data yang tidak berkaitan dengan permasalahan penelitian dibuang.

c. Penyajian data, dalam penyajian data ini peneliti menyajikan hasil penelitian, bagaimana temuan-temuan baru itu dihubungkan dengan penelitian terdahulu.

d. Penarikan kesimpulan, pada tahapan ini peneliti membuat kesimpulan apa yang ditarik dan saran sebagai bagian akhir dari penelitian.

\section{Pengecekan Keabsahan Temuan}

Untuk meyakinkan bahwa data yang diperoleh sudah dapat menjawab permasalahan yang ada dan terbukti kebenaranya, maka peneliti melakukan uji keabsahan data. Adapun langkahlangkah yang ditempuh peneliti terkait dengan hal ini adalah memperpanjang kehadiran peneliti di lapangan yaitu dari minggu Kedua bulan Nopember 2017 sampai minggu keempat bulan Januari 2018, dilakukan dalam bentuk observasi dan penggalian informasi yang sifatnya mendalam dengan para informan. 
Jurnal Ilmiah Al-Jauhari (JIAJ)

Studi Islam dan Interdisipliner

Volume 3 No 2 September 2018

ISSN 2541-3430 E-ISSN 2541-3449

\section{HASIL PENELITIAN}

Berdasarkan penuturan informan dapat dianalisis bahwa tingat partisifasi wanita karier dalam pembinaan spiritual dan pembentukan karakter anak Kecamatan Tapa Kabupaten Bone Bolango sangat tinggi yang tidak hanya dipahami berdasarkan tataran konseptual yang kaku yaitu lebih mengutamakan kerja diluar rumah ketimbang urusan rumah tangga, akan tetapi dalam berkiprah dilingkungan sosial yang lebih luas,sebagai wanita atau ibu dari anak - anak atau istri dari seorang suami, mereka juga tidak melupakan tanggung jawabnya dirumah tangga dan mampu menciptakan keberhasilan terhadap semua anggota keluarga.

Upaya yang dilakukan wanita karier terhadap pembinaan kecerdasan spiritual dan pembentukan karakter anak di Kecamatan Tapa Kabupaten Bone Bolango menurut informan, bahwa wanita karier Aparatur sipil Negara di Kecamatan Tapa Kabupaten Bone Bolango sering memberikan contoh keteladanan pada anak - anaknya tentang hal - hal yang mengarah pada pembinaan kecerdasan spiritual dan pembentukan karakter anak kearah yang positif.Oleh karena dinyakini sepenuhnya oleh mereka bahwa contoh teladan orang tua adalah motivasi terbesar bagi anak - anaknya untuk melakukan sesuatu terbaik yang diperintahkan oleh orang tuanya.

Kendala yang dihadapi wanita karier dalam pembinaan kecerdasan spiritual dan pembentukan karakter anak adalah Pertama : Tingkat pendidikan dan pengetahuan orang tua dalam mendidik.Kedua : Kondisi lingkungan masyarakat yang kurang baik. Ketiga : Kurangnya waktu bagi orang tua untuk berkomunikasi dengan anak - anaknya. 


\section{E. PENUTUP}

\section{Kesimpulan}

1. Tingkat partisipasi wanita dalam pembinaan kecerdasan spiritual dan pembentukan karakter anak di Kecamatan Tapa Kabupaten Bone Bolango ditunjukkan melalui pengasuhan anak sepenuhnya dilakukan oleh orang tua, pembiasaan atau pemberian contoh teladan kepada anak-anak dalam lingkup penanaman akhlakul qarimah, orang tua selalu memperhatikan cara belajar anak, orang tua membuat program kegiatan yang harus dilakukan oleh anak-anaknya dalam setiap hari, orang tua meskipun aktivitas keseharian lebih banyak berada di luar rumah, tetapi selalu berusaha untuk memenuhi tugas dan tanggung jawabnya dalam mendidik anak-anaknya agar memiliki pengetahuan aqidah dan akhlak secara dini serta mampu mengaplikasikan nilai-nilai aqidah dan akhlak terpuji dalam kehidupan sehari-hari.

2. Upaya yang dilakukan wanita karier dalam pembinaan kecerdasan spiritual dan pembentukan karakter anak di Kecamatan Tapa Kabupaten Bone Bolango di antaranya; a) melakukan pendidikan aqidah dan akhlak secara intesif kepada anak melalui mempraktekkan amalan ibadah di dalam kehidupan sehari-hari, seperti shalat lima waktu, puasa, membaca al-Qur"an, dan amalan ibadah lainnya. Sedangkan pendidikan akhlak dilakukan dengan cara penanaman etika dan moral dalam keluarga, memperkenalkan kepada anak-anak cara hidup menghargai sesama manusia dan makhluk lainnya di lingkungan sekitarnya, serta mengajari anak agar selelu bersyukur dan bersabar untuk mengakui kebesaran Ilahi atas apa yang terjadi kepada makhluk ciptaan-Nya; b) memberikan contoh keteladan yang baik kepada anak pada semua aspek; c) memasukkan anak ke lembaga-lembaga pendidikan agama, atau mengikutsertakan anak pada setiap kegiatan keagamaan, serta membiasakan anak membaca buku-buku tentang Aqidah dan Akhlak; d) melakukan pengawasan terhadap semua aktivitas anak terutama; cara belajar anak, sikap ramah anak terhadap orang lain, cara bergaul anak dengan yang lebih muda, sederajat atau yang lebih tua, yang kesemuanya disertai dengan penetapan puneshman dan reward atas perbuatan yang mereka lakukan.

3. Kendala yang dihadapi wanita karier dalam pembinaan kecerdasan spiritual dan pembentukan karakter anak di Kecamatan Tapa Kabupaten Bone Bolango, di antaranya; a) rendahnya tingkat pendidikan dan pengetahuan orang tua dalam mendidik anak; b) kondisi 
lingkungan masyarakat yang kurang baik; c) kurangnya waktu bagi orang tua untuk berkomunikasi dengan anak-anaknya atau tidak maksimalnya melaksanakan tugas dan tanggungjawab mengurus anak sepanjang hari jika pada saat-saat tertentu ada pekerjaan kantor atau kedinasan yang harus diselesaikan. Adapun upaya yang dilakukan untuk mengatasi kendala-kendala tersebut di antaranya; a) memperbanyak membaca buku-buku tentang bagaimana tatacara wanita karier dalam pembinaan kecerdasan spiritual dan pembentukan karakter anak di Kecamatan Tapa Kabupaten Bone Bolango ke arah yang lebih baik; b) memperbanyak bertanya kepada orang lain yang memiliki pengetahuan dan sukses mendidik anak-anaknya hingga melahirkan anak yang berperilaku baik, tekun ibadah dan mempunyai masa depan yang gemilang; c) menjadikan lingkungan keluarga yang selalu hidup dalam suasana religius; d) membuat time schedule kegiatan yang memungkinkan orang tua dan anak dapat berkomunikasi secara intensif menuju ketercapaian keluarga yang harmonis dan penuh keakraban.

\section{B. Rekomendasi}

Pola pembinaan kecerdasan spiritual dan pembentukan karakter anak sudah seharusnya dilakukan berdampingan dengan pola pembentukan keluarga bahagia yang dipenuhi dengan cinta kasih dan berbingkai agama. Untuk itu sebagai orang tua terutama seorang ibu yang banyak beraktivitas di luar rumah atau disebut wanita karier, seyogyanya tidak boleh mengensampingkan tanggungjawabnya yang utama yaitu mendidik anak-anaknya agar mereka berkepribadian mulia dan memiliki masa depan yang cerah. Untuk mengatasi berbagai kendala yang dihadapi wanita karier dalam pembinaan kecerdasan spiritual dan pembentukan karakter anak, diharapkan orangtua mencari referensi tentang tatacara wanita karier dalam pembinaan kecerdasan spiritual dan pembentukan karakter anak ke arah yang lebih baik. 


\section{DAFTAR PUSTAKA}

Alang, Sattu, Kesehatan Mental Dan Terapi Islam Makassar: Berkah Utami, 2009.

Albar, Muhammad, Amar al-Mar"eah Fii al-Mizan, diterjemahkan oleh Amir Hamzah Fachruddin, Wanita Karier dalam Timbangan Islam; Kodrat Kewanitaan, Emansipasi dan Pelecehan Seksual Jakarta: Pustaka Azzam, 2008.

al-Bukhari, Muhammad bin Ismail Abu Abdillah, Shahih Bukhari, Juz II Beirut: Dar Ibn Katsir, 1987.

al-Buthi, M. Said Ramadhan, Perempuan antara Kezaliman Sistem Barat dan Keadilan Islam Solo: Intermedia, 2012.

al-Ghazali, Mohammad, Al-Islam wa Al-Thaqat al-Mu"attalat Kairo: Dar Al-Kutub AlHaditsah,

al-Ghazali, Mohammad, Ihya „Ulumuddin, tentang Keajaiban Hati Jakarta: Yayasan Kesejahteraan Keluarga, 1965.

Aly, Hery Nur dan Munzir S., Watak Pendidikan Islam Jakarta: Friska Agung Insani, 2013.

Arikunto, Suharsimi, Prosedur Penelitian; Suatu Pendekatan Praktis Jakarta: Rineka Cipta, 2011.

Asmuni, H.M. Yusran, Dirasah Islamiyah, Fokus Kajian Fiqh, Jakarta : Pt Raja Grafindo Persada, 2001

Azra, Azyumardi, Pendidikan Islam Tradisi dan Modernisasi Menuju Millenium Baru, Jakarta: Kalimah, 2002.

bin Hambal, Ahmad, Musnad al-Imam Ahmad bin Hambal Beirut, Al-Maktab al-Islami, Daar alSadeer, 2008.

Budiningsih, Asri, Pembelajaran Moral Berpijak pada Karakteristik Siswa dan Budayanya Jakarta: Rineka Cipta, 2009.

Daradjat, Zakiah,"Peran Ganda dan Kepemimpinan Perempuan” dalam Lily Zakiah Munir [ED], Memposisikan Kodrat: Perempuan dan Perubahan dalam Perspektif Islam Bandung: Mizan, 2009.

Daryanto, S.S. Kamus Bahasa Indonesia Lengkap Surabaya: Apollo, t.th.

Departemen Agama RI. Al-Qur"an dan Terjemahnya, Jakarta: Gema Risalah Press Bandung, 2009.

Departemen Pendidikan dan Kebudayaan, Kamus Besar Bahasa Indanesia Jakarta, Balai Pustaka, 2007. 
Jurnal Ilmiah Al-Jauhari (JIAJ)

Studi Islam dan Interdisipliner

Volume 3 No 2 September 2018

ISSN 2541-3430 E-ISSN 2541-3449

Farozin, Muh. \& Kartika Nur Fathiyah, Pemahaman Tingkah Laku Yogyakarta: Rineka Cipta, 2003.

Fatimah, Nasib Umar, Menggugat Sejarah Perempuan"Mewujudkan Idealisme Jender Sesuai Tuntutan Islam, Jakarta: Cendekia Sentra Muslim, 1993.

Gibran, Kahlil, dalam M. Rusli Karim, Mendidik Manusia Merdeka Yogyakarta: Pelita Baru, 1997.

Hadi, Sutrisno, Metodologi Research Jakarta: UGM Press, 2010.

Harb, Muhammad Thal ${ }^{\text {ee } a t, ~ S o l u s i ~ I s l a m ~ t e r h a d a p ~ D i l e m a ~ W a n i t a ~ K a r i e r ~ Y o g y a k a r t a: ~ W i h d a h ~}$ Press, 2014.

Hartati, Netty, dkk., Islam dan Psikologi Jakarta: RajaGrafindo Persada, 2005.

Ibrahim bin Ali al-Wazir, ,Ala Masyarif Al-Qarn Kairo, Dar Al-Syuruq, 1998.

Khomaini, Imam dalam Majalah Payam Khonewodeh No: 52, 1384 H.

Langgulung, Hasan, Beberapa Tinjauan dalam Pendidikan Islam Jakarta: Pustaka Antara, 1980.

Mahmud, Jamaluddin Muhammad, Huquq Al-Mar"at fi Al-Mujtama" al-Islamiy Kairo, Al-Haiat al-Mishriyat al-Amat, 2006.

Mahzar, Armahedi “Wanita dalam Islam” kata pengantar, dalam buku Fatima Mernissi, Woman And Islam: An Historical and Theological Enqiury diterjemahkan oleh Yasiar Radianti dengan judul Wanita dalam Islam Bandung: Pustaka, 2011.

Mernissi, Fatima, Woman And Islam: An Historical and Theological Enqiury Bandung: Pustaka, 2009.

Muhajir, Noeng, Metode Penelitian Kualitatif Yogyakarta: Rake Sarasin, 2009.

Munir, Lily Zakiah (ED), Memposisikan Kodrat: Perempuan dan Perubahan dalam Perspektif Islam Bandung: Mizan, 2009.

Narbuko, Cholid dan Abu Achmadi, Metodologi Penelitian Jakarta: Bumi Aksara, 2010.

Pasaribu dan Simanjuntak, Proses Belajar Mengajar Bandung: Tarsito, 1982.

Poerwanto, M. Ngalim, Ilmu Pendidikan Teoritis dan Praktis Bandung: Remaja Rosdakarya, 2008.

Purwanto, Ngalim, Psikologi Pendidikan Bandung: Remaja Karya, 2010.

Shihab, Umar, Menggugat Sejarah Perempuan”Mewujudkan Idealisme Jender Sesuai Tuntutan Islam, Jakarta: Cendekia Sentra Muslim, 2009.

Sjarkawi, Pembentukan Kepribadian Anak; Peran Moral, Intelektual, Emosional, dan Sosial sebagai Wujud Integritas Membangun Jati Diri Jakarta:. Bumi Aksara, 2011.

Subagyo, Joko, Metode Penelitian dalam Teori dan Praktek Jakarta: Rineka Cipta, 2011. 
Jurnal Ilmiah Al-Jauhari (JIAJ)

Studi Islam dan Interdisipliner

Volume 3 No 2 September 2018

ISSN 2541-3430 E-ISSN 2541-3449

Sukardi, Metodologi Penelitian Pendidikan Kompetensi dan Praktiknya Jakarta: Bumi Aksara, 2005.

Sukmadinata, Nana Syaodih, Landasan Psikologi Proses Pendidikan Bandung: Remaja RosdaKarya, 2005.

Suryabrata, Sumadi, Psikologi Kepribadian Jakarta: RajaGrafindo Persada, 2006.

Syalaby, Ahmad, Kehidupan Sosial dalam Kehidupan Islam T.t: Amzah, 2011.

Umar, Nasarudin, Argumen Kesetaraan Gender; Perspektif Al-Quran Jakarta; Paramadina,1999.

Warsito, Hermawan, Pengantar Metodologi Penelitian, Buku Panduan Mahasiswa Jakarta:

Gramedia Utama, 2000 
Jurnal Ilmiah AI-Jauhari (JIAJ)

Studi Islam dan Interdisipliner

Volume 3 No 2 September 2018

ISSN 2541-3430 E-ISSN 2541-3449 
Jurnal Ilmiah AI-Jauhari (JIAJ)

Studi Islam dan Interdisipliner

Volume 3 No 2 September 2018

ISSN 2541-3430 E-ISSN 2541-3449 